\title{
Molecular Characterization of Desi Cotton Hybrids using SSR Markers for Boll Size Improvement
}

\author{
Meghraj T. Chavhan ${ }^{1 *}$, D. R. Rathod ${ }^{1}$, B. S. Taynath ${ }^{1}$, P. N. Bhojane ${ }^{1}$, S. B. Deshmukh ${ }^{2}$, \\ S. J. Gahukar ${ }^{1}$, A. S. Bhande ${ }^{1}$ and P. A. Mohanapure ${ }^{1}$ \\ ${ }^{1}$ Biotechnology Centre, Department of Agril. Botany, Dr PDKV, Akola, MS, India \\ ${ }^{2}$ Cotton Research Unit, Dr PDKV, Akola, MS, India \\ *Corresponding author
}

\section{A B S T R A C T}

Keywords

Desi cotton, SSR; Polymorphism, PCR, Hybrids

Article Info

Accepted:

04 December 2020

Available Online:

10 January 2021
The present study was attempted with the purpose to introgress genes harboring big bollness to enrich gene pool of $G$. arboreum desi cotton popular varieties viz., AKA-7 (P1), Phule Dhanwantari (P2) from donor parent's G. cernuum (D1) and PA-812 (D2). Four single cross hybrids namely SC-I (AKA - 7 x G. cernuum), SC-II (AKA-7 x PA812), SC-III (PD x G.cernuum) and SC-IV (PD x PA-812) were attempted using above lines by manual emasculation and pollination. Accordingly, a total of 333 crosses were attempted, out of these, a total of 55 crosses made successful. Parental polymorphism and genetic diversity was assessed using 20 SSRs, where seven SSR found polymorphic. A dendrogram was constructed using Jaccard's similarity coefficient and genotypes were grouped into three clusters based on the SSR profile. A lowest similarity coefficient value (0.80) was found between P1 and D1 indicated high genetic diversity occurred between them. The highest similarity coefficient value $(0.90)$ in P2 and D2 was noticed, indicating low diversity exists between them. Among SSRs, only BNL-3580 showed the highest level of polymorphism $94 \%$. From 55 successful, 18 single cross hybrids were confirmed as true hybrids by SSR genotyping proving SSRs as excellent genomic tools for parentage confirmation and hybridity determination.

\section{Introduction}

The word cotton derives from the Arabic word KUTON (Brown et al., 1958). Cotton belongs to the genus Gossypium and family Malvaceae. Cotton is the king of fiber crops and is India's most significant agricultural crop. The genus Gossypium is composed of 50 species among which four could be cultivated with spinnable lint, and about 44 are wild diploids whereas the remaining two are wild tetraploids (Percival and Kohel, 1990). For the four species cultivated $G$. hirsutum and $G$. barbadense is widely referred to as new world cotton, which are tetraploid $(2 \mathrm{n}=4 \mathrm{x}=52)$ whereas $G$. herbaceum $L$. and $G$. arboreum $L$. they are diploid $(2 n=2 x=26)$ with A-genome and are generally referred to as Old World Cotton, or Desi Cotton. G. arboreum also serves as a germplasm resource for current breeding programs due to many desirable cotton 
cultivation features such as early maturity, good abiotic stress tolerance, high fiber resistance, high oil content, high seed index, and excellent plasticity. Several tests have shown that Asian cotton is resilient and displays exceptional tolerance to a variety of pests and diseases, including bollworms (Dhawan et al., 1991), leafhoppers and aphids (Nibouche et al., 2008), rust, fungal (Wheeler et al., 1999) and viral (Mehtre et al., 2004; Akhtar et al., 2010) diseases (Sethi et al., 2014). Before, the introduction of Bt cotton, in different parts of the world, including Gujarat Maharashtra and northern India, the desi cotton was grown on around 27 percent area (Lalitha et al., 2014). The American cotton increased primarily due to its longer length of staple, which was the need for mechanized textile making that requires stronger fiber. But still short-staple cotton is strongly in demand today due to its desirable characteristics features. The cultivation of American cotton varieties and hybrids became more risky and non-remunerative and created socio-economic stress among cotton growers (Naik et al., 2005). Higher crop costs in these American Bt cotton hybrids are due to high occurrence of pink boll worm, high seed costs more plant security to sucking pest and higher fertilizer dose is needed. On the contrary, desi (G.arboreum) cotton virtually involves lower seed cost, lesser cost for plant protection and crop nutrition. Looking to this balance sheet one will be really optimistic for cultivation of desi cotton provided they should yield at least equal to varieties and hybrids of tetraploid cotton and must possess equivalent fibre properties. For potential growth in the fiber industry, enhancement of gene pool with genetic diversity is desperately needed (Abdalla et al., 2001), altogether with the production of new desi cotton verities with desirable traits of interest and to complete the demand of cotton growing farmers with big boll size in desi cotton owing to its ease in the manual hand picking as well as the economics of crops production. Studies evaluated the genetic diversity of landraces in G. arboreum L. race by using simple sequence repeats (SSRs) (Liu 2007), where the result of these studies revealed a higher level of genetic variation at the DNA level among the G. arboreum accessions than that among $G$. hirsutum L. accessions. The transition of intraspecific and interspecific hybridization of allelic diversity from different cotton germplasm services to the main cotton breeding gene pools would be an important step in this direction (Sethi et al., 2015). The current study focuses on genetic improvement by using molecular breeding approaches for the production of highly desirable desi cotton verities with traits of interest. Among DNA based makers, simple sequence repeats (SSR) are most widely called microsatellites and have been identified first in humans (Litt and Lutty, 1989). These are short tandem repeats of 2-8 nucleotide motifs. The SSRs are flanked by unique sequences that have remained conserved over the course of evolution between the members of a gene pool. SSRs are known to be strongly polymorphic (Powell et al., 1996) and polymorphism is caused either by slipping DNA polymerase during replication or by uneven crossing, which results in variations in the number of copies of the core nucleotide sequences (Rahman et al., 2002). Microsatellites are considered ideal markers in gene mapping studies because of their abundance in the genome and the codominant nature (Han et al., 2006). SSRs are highly reliable, allow data exchange across labs and are more robust than RAPD and AFLP. With a large number of samples this process is cheap, fast and quick to detect by gel electrophoresis. Their locus-specific character and co-dominant nature enables them being remarkable for functional plant breeding and also for multiple purposes. Because of the broad genome coverage and the higher variable existence of SSR or microsatellite 
markers, they are the markers of choice for any application in plants. SSR procedures are excellent genomic tools for parentage confirmation and hybridity determination and may enhance the efficiency of breeding programmes (Rao et al., 2015).

\section{Materials and Methods}

During the present study, experimental materials comprised of phenotypically contrasting four genotypes of desi cotton $(G$. arboreum L.) were obtained from the Cotton Research Unit (CRU), Dr. Panjabrao Deshmukh Krishi Vidyapeeth (PDKV), Akola. The plant material for this study comprised of fifty-five single cross hybrids and their male and female parents: Gossypium arboreum cernuum race obtained from CICR,
Nagpur; PA-812 obtained from VNMKV, Parbhani; AKA-7 obtained from Dr.PDKV Akola; Phule Dhanwantari obtained from MPKV, Rahuri. The completely homozygous seeds of following promising and diverse parental genotypes of desi (G. arboreum L.) cotton were used and their contrasting features are given under Table 1.

The four different single crosses (SC) were made using four diverse arboreum genotypes. AKA-7 and Phule Dhanwantari (PD) were used as female parents. G. cernuum race and PA-812 these were phenotypically contrasting to the corresponding female parents and were used as male parents. Accordingly, four single crosses were performed during present investigation namely SC-I $\left(\mathrm{P}_{1} \times \mathrm{DD}_{1}\right), \quad \mathrm{SC}-\mathrm{II}$ $\left(\mathrm{P}_{1} \times D_{2}\right)$, SC-III $\left(\mathrm{P}_{2} \times D_{1}\right)$ and SC-IV $\left(\mathrm{P}_{2} \times D_{2}\right)$.

\section{Intraspecific Hybridization}

\begin{tabular}{|c|c|c|c|}
\hline Sr. No. & $\begin{array}{c}\text { Name of Single } \\
\text { Cross }\end{array}$ & & Hybridization Programme \\
\hline $\mathbf{1}$ & $\mathrm{SC}-\mathrm{I}$ & $\left(\mathrm{P}_{1} \times \mathrm{D}_{1}\right)$ & AKA-7 x G. arboreum race cernuum \\
\hline $\mathbf{2}$ & $\mathrm{SC}-\mathrm{II}$ & $\left(\mathrm{P}_{1} \times \mathrm{D}_{2}\right)$ & AKA-7 x PA-812 \\
\hline $\mathbf{3}$ & $\mathrm{SC}-\mathrm{III}$ & $\left(\mathrm{P}_{2} \times \mathrm{D}_{1}\right)$ & $\begin{array}{c}\text { Phule Dhanawantari x } \text { G. arboreum race cernuum } \\
\text { Collection }\end{array}$ \\
\hline $\mathbf{4}$ & $\mathrm{SC}-\mathrm{IV}$ & $\left(\mathrm{P}_{2} \times \mathrm{D}_{2}\right)$ & Phule Dhanawantari $\mathrm{PA}-812$ \\
\hline
\end{tabular}

\section{Results and Discussion}

\section{SSR molecular marker Analysis}

DNA of four parents (AKA-7, Phule Dhanawantari, G. cernuum and PA812) with each of the four single cross $F_{1}$ hybrid form segregating lines of all 55 selected plants was extracted by using young leaves by modified CTAB method (Sharma et al., 2002). The DNA samples extracted were electrophorised on 0.8 percent Agarose gel for quality confirmation. For the quantitative assay, a stock DNA sample of each parent and $F_{1} s$ was quantified on nano-photometer. The PCR analysis using available SSR (microsatellite) markers was carried out using primers to study parental polymorphism. Amplification was performed in a volume of $20 \mu \mathrm{l}$ containing $1 \mu \mathrm{l}$ of DNA $(50 \mathrm{ng} / \mu \mathrm{l}), 1 \mu \mathrm{l}$ of each primer, $0.4 \mu \mathrm{l}$ of dNTPs, $0.5 \mathrm{U}$ Taq polymerase and 1X PCR buffer. Thirty five cycles, each consisting of 1 min denaturation, $1 \mathrm{~min}$ at annealing temperature separately for each primer pair, and 1 min polymerization and extension for 10 min were performed in a thermo cycler (Bio-Rad, USA). The PCR products were separated by electrophoresis in a vertical gel system at $100 \mathrm{~V}$ for $4 \mathrm{~h}$ in $10 \%$ PAGE to check polymorphism among parents. The master mix for each primer was prepared separately as described in following Table 2. 


\section{Scoring the amplified fragments}

The amplification of DNA profiles for all primers was compared, and the DNA bands were graded as present (1) or absent (0) (Singh et al., 2006) at each amplification stage of each primer, thereby producing the 0 , 1 matrix. Percent polymorphism was calculated by using a formula, Percent polymorphism $(\%)=$ (Total No. of polymorphic bands) / (Total No. of bands generated by 40 primers) x $100 \%$ (Alkuddsi et al., 2013).

The amplification products were scored across the lanes comparing their respective molecular weights. Each band was treated as one SSR marker. Bands were scored from photographed gel image captured using gel document system installed at Molecular Biology Laboratory, Biotechnology Centre, Dr. PDKV, Akola. Data analyses were performed using the NTSYS-Pc (Numerical taxonomy System, version 2.02). Dendrogram (Fig. 3) was constructed using unweighted pair group method for arithmetic mean (UPGMA) based on Jaccard's coefficient. Detail list of SSR primers used for molecular assay with their nucleotide sequences and mean performance of four plants of each cotton genotypes for 15 different quantitative characters is given in table 3 and 4 respectively.

The PCR analysis using available SSR (microsatellite) markers was carried out using primers to study parental polymorphism. After the PCR analysis and staining of gel it was photographed under Gel Documentation system.

The representative gel images of SSR genotyping in parents showing the SSR marker and its parental polymorphism is depicted in Fig. 1 and details of SSR marker tested is given in Table 3 .
The Details of the graphical representation showing distribution of SSR markers used, tested, its polymorphism percent on 13 chromosomes is depicted in Fig. 2.

Out of 20 microsatellite markers, seven microsatellite markers found polymorphic and hence these markers were screened in single cross $F_{1 s}$ population to confirm the hybridity. Among the 20 microsatellite makers, NAU4024, BNL-226, BNL-3347, BNL-1694, BNL-4049, NAU-2000 and BNL-3580 were found polymorphic among the parents with polymorphic level of $20,25,30,35,40$, and $94 \%$.

The remaining markers were found monomorphic. The similarity matrix was constructed based on Jaccard's similarity coefficient which gives the extent of similarity between two genotypes. A lower similarity coefficient value indicates high diversity among the genotype. Cluster analysis was carried out using the Unweighted Pair Group Method with arithmetic Mean (UPGMA) clustering algorithm. The similarity matrix and dendrogram were constructed using the XLSTAT software (https://www.xlstat.com/).

The similarity matrix thus obtained is depicted in table 5. From the Table 5 similarity matrix and dendrogram analysis (Fig. 3), the selected four genotypes were classified into three clusters as represented in Table 5. In this study the similarity matrix coefficient ranged from 0.800 to 0.903 between 4 genotypes. A lowest similarity coefficient value (0.800) in between AKA-7 and G.cernuum indicated high diversity between them. A highest similarity coefficient value (0.903) in PA-812 and Phule Dhanwantari and indicates low diversity between them. This confirmed the genetic diversity exist among the cotton genotype selected for hybridization programme. 


\section{Hybridity confirmation}

For microsatellite polymorphisms, the single cross hybrids and their parents were analyzed. All single cross hybrids obtained were subjected for hybridity confirmation with their respective parents. Seven informative markers were identified in the parental polymorphism study, among which BNL3580 was considered highly polymorphic which was used to imprint the hybrids. Fig. 4 depicts gel pictures demonstrating amplification in the parents and hybrids of those confirmed. The polymorphism found between the active parents used as hybrid recognition markers, whether they were genuine hybrids. Comparing parents 'SSR banding habits with the respective hybrids, genuine hybrids have been confirmed (Fig. 4). BNL-3580 primer demonstrated specific alleles in both female $\mathrm{P}_{1}$ (AKA-7) and male parent $\mathrm{D}_{1}(G$. cernuum) i.e., SC-I.

However, single cross hybrid (SC-I) exhibited the alleles of both parents, Confirm the heterozygosity of the hybrid, with the inclusion of two parent bands. Gel pictures demonstrating amplification in the parents and hybrids, Fig.4(a) Lane no.4, 5, 6 and 7 i.e, of (SC-I). Indicating the contribution of both the parents involved in the crossing and expressed equally confirming these as true hybrids.

Table.1 Details of contrasting features of diverse parents used for the development of individual single cross $F_{1}$ hybrids

\begin{tabular}{|c|c|c|c|}
\hline S.N. & Female parents & Characters & Source \\
\hline 01 & AKA-7 $\left(\mathrm{P}_{1}\right)$ & $\begin{array}{l}\text { Well adapted, high yielding, small } \\
\text { boll wt }(2.0-2.5 \mathrm{~g}) \text {, medium staple } \\
\text { length }(22-23 \mathrm{~mm}) \text {, medium fine } \\
\text { fiber, less locule retention, early } \\
\text { maturing (140-150 days), }\end{array}$ & PDKV, Akola \\
\hline 02 & $\begin{array}{l}\text { Phule } \\
\text { Dhanawantari }\left(\mathrm{P}_{2}\right)\end{array}$ & $\begin{array}{l}\text { Well adapted, high yielding, Zero } \\
\text { monopodial, high locule retention, } \\
\text { medium boll weight }(3.5-4.0 \mathrm{~g}) \text {, short } \\
\text { staple length }(19-20 \mathrm{~mm}) \text {, coarse } \\
\text { fiber ( } 6.0 \mu \mathrm{g} / \mathrm{inch}) \text { and medium } \\
\text { maturity (160 days) }\end{array}$ & MPKV, Rahuri \\
\hline 03 & $\begin{array}{l}\text { Gossypium } \\
\text { arboreum race } \\
\text { cernuum } \\
\text { Indigenous } \\
\text { Collection }\left(\mathrm{D}_{1}\right)\end{array}$ & $\begin{array}{l}\text { Low adaptability, low yield, high } \\
\text { boll weight }(5-5.5 \mathrm{~g}) \text {, short fiber } \\
\text { length }(18-19 \mathrm{~mm}) \text {, coarse fiber } \\
(7.0 \mu \mathrm{g} / \mathrm{inch}) \text {, high locule retention, } \\
\text { longer duration }(>180 \text { days })\end{array}$ & CICR, Nagpur \\
\hline 04 & P A- $812\left(D_{2}\right)$ & $\begin{array}{l}\text { High yielding, small boll weight (2- } \\
2.5 \mathrm{~g}) \text {, Staple length }(30 \mathrm{~mm}) \text { and } \\
\text { high fiber strength }(29 \mathrm{~g} / \mathrm{tex}) \text { fine } \\
\text { fiber }(4.5 \mu \mathrm{g} / \mathrm{inch}) \text {, medium maturity } \\
(150-160 \text { days })\end{array}$ & VNMKV, Parbhani \\
\hline
\end{tabular}


Table.2 Details of PCR components for SSR analysis of desi cotton

\begin{tabular}{|l|c|c|c|}
\hline Components & Concentration in stock & $\begin{array}{c}\text { Concentration in } \\
\text { Reaction }\end{array}$ & Quantity \\
\hline Nucleus Free water & --- & -- & $13.9 \mu \mathrm{l}$ \\
\hline $\begin{array}{l}\text { Buffer } \\
\text { Mgcl2 }\end{array}$ & $\begin{array}{c}10 \mathrm{X} \text { with } 17.5 \mathrm{mM} \\
\mathrm{Mgcl}_{2} 50 \mathrm{mM}\end{array}$ & $1 \mathrm{X}$ & $2.5 \mu \mathrm{l}$ \\
\hline DNTPs & $10 \mathrm{mM} \mathrm{each}$ & $0.4 \mathrm{mM} \mathrm{each}$ & $0.40 \mu \mathrm{l}$ \\
\hline Primer & $10 \mathrm{Um}$ & $0.2 \mu \mathrm{M}$ & $1 \mu \mathrm{l}$ \\
\hline $\begin{array}{l}\text { Taq DNA } \\
\text { polymerase }\end{array}$ & 5 unit $\mu \mathrm{l}^{-1}$ & $1 \mu \mathrm{l}$ & $0.20 \mu \mathrm{l}$ \\
\hline DNA $(50 \mathrm{ng})$ & $50 \mathrm{ng} / \mu \mathrm{l}$ & $50 \mathrm{ng}$ per reaction & $1 \mu \mathrm{l}$ \\
\hline & & Total & $\mathbf{2 0} \boldsymbol{\mu l}$ \\
\hline
\end{tabular}

Table.3 Detail list of SSR primers used for molecular assay with their nucleotide sequences

\begin{tabular}{|c|l|l|l|}
\hline Sr.No. & Primer & Forward & Reverse \\
\hline $\mathbf{1}$ & BNL-580 & CTATGTTTGGCCTTGGCATT & TAGTGACAGATATCCCCGGC \\
\hline $\mathbf{2}$ & BNL-226 & TTATTCTCACAGCCGGAACC & TTCACCCTCTCGCTTCTCAT \\
\hline $\mathbf{3}$ & BNL-3537 & TGAAATGGACGTGACATGGT & TTGCAGGTTCTGATGAGCAG \\
\hline $\mathbf{4}$ & NAU-4024 & ACAAGCATCTTCATGGACCT & AGAAGGATGATGCAAAGAGG \\
\hline $\mathbf{5}$ & BNL-3535 & CTGGGATACATACCGTGGCT & ACTTTGCTGAATAAAGGTGAGTG \\
\hline $\mathbf{6}$ & BNL-2656 & AACCACAACCAAAATTCACG & CTTTGGTTTCGTAGGGCTTG \\
\hline $\mathbf{8}$ & BNL-3347 & AGACTGACATGCAGCTTCCA & ATCTTAATTTGAGTATAGGATAGGGG \\
\hline $\mathbf{9}$ & BNL-3031 & AGGCTGACCCTTTAAGGAGC & AACCAACTTTTCCAACACCG \\
\hline $\mathbf{1 0}$ & BNL-448 & TAGAACATAGGGAGGCGTGG & AATGGAGAGACAATGATTTTCG \\
\hline $\mathbf{1 1}$ & BNL-3580 & CTTGTTTACATTCCCTTCTTTATAC & CACGCAAGCTTGGTCAATACC \\
\hline $\mathbf{1 2}$ & BNL-1434 & $\begin{array}{l}\text { AAATTCAAGAATCAAAAAACAAC } \\
\text { A }\end{array}$ & TTATGCCAAAGTATATGGAGTAACG \\
\hline $\mathbf{1 3}$ & BNL-4049 & AGCTGTGGAACCAATTGACC & ATATCATTTTACTACTGCTTTTGTGTG \\
\hline $\mathbf{1 4}$ & BNL-3992 & CAGAAGAGGAGGAGGTGGAG & TGCCAATGATGGAAAACTCA \\
\hline $\mathbf{1 5}$ & BNL-542 & TCGATCACATTTATAAGAACTATT & TTCATTTTGAACATTCGCCA \\
\hline $\mathbf{1 6}$ & BNL-3241 & GTATTAAAATAATAAGAGTCTAAT & GACCATGGACCGAGTTGAGT \\
\hline $\mathbf{1 7}$ & BNL-1694 & CGTCCC & \\
\hline $\mathbf{1 8}$ & BNL-686 & ATTTTTCCCTTGGTGGTCCT & ACATGATAGAAATATATAAACCAAACACG \\
\hline $\mathbf{1 9}$ & NAU-5499 & ATAAACTTTCCCGGCTGATT & CCAGCACAAGACTTGATTGT \\
\hline $\mathbf{2 0}$ & NAU-2000 & GAAAATGTTCCCCTCTTGTG & CTAAAGGGGACCAAAGCTG \\
\hline & & & \\
\hline
\end{tabular}


Table.4 Mean performance of four plants of each cotton genotypes for 15 different quantitative characters

\begin{tabular}{|c|c|c|c|c|c|}
\hline Sr.No. & Quantitative characters & AKA-7 & $\begin{array}{c}\text { Phule } \\
\text { Dhanwantari }\end{array}$ & $\begin{array}{c}\text { Race } \\
\text { Cernnum } \\
\text { G.arboreum }\end{array}$ & PA-812 \\
\hline $\mathbf{1}$ & Days to 1 ${ }^{\text {st }}$ flower & 45 & 51 & 48 & 55 \\
\hline $\mathbf{2}$ & Days to 50 \% flowering & 65 & 70 & 72 & 68 \\
\hline $\mathbf{3}$ & Days to 1 st boll bursting & 115 & 112 & 118 & 108 \\
\hline $\mathbf{4}$ & Plant height(cm) & 95 & 80 & 60 & 120 \\
\hline $\mathbf{5}$ & No. of mop/plant & 1.8 & 1.0 & 1.4 & 2.0 \\
\hline $\mathbf{6}$ & No. of sym/ plant & 27 & 25 & 18 & 33 \\
\hline $\mathbf{7}$ & No. of bolls/plant & 30 & 27 & 15 & 40 \\
\hline $\mathbf{8}$ & Boll weight(g) & 2.5 & 2.8 & 4.2 & 3.4 \\
\hline $\mathbf{9}$ & Seed index(g) & 5.5 & 4.2 & 6.4 & 5.9 \\
\hline $\mathbf{1 0}$ & SCY/plant & 33 & 25 & 20 & 26 \\
\hline $\mathbf{1 1}$ & Ginning outturn $(\%)$ & 32.63 & 28.75 & 22.66 & 29.67 \\
\hline $\mathbf{1 2}$ & Lint index (g) & 3.40 & 3.70 & 4.37 & 3.95 \\
\hline $\mathbf{1 3}$ & Halo length & 22 & 20 & 17 & 28 \\
\hline $\mathbf{1 4}$ & Fiber strength & 24 & 22 & 17 & 29 \\
\hline $\mathbf{1 5}$ & Locule Retention & Low & Low & High & Moderate \\
\hline
\end{tabular}

Table.5 Jaccard's similarity co-efficient matrix obtained using four cotton Genotypes

\begin{tabular}{|l|c|c|c|c|}
\hline \multicolumn{1}{|c|}{ Genotype } & AKA-7 & Phule Dhanwantari & G.cernuum & PA-812 \\
\hline AKA-7 & 1 & 0.803 & 0.800 & 0.862 \\
\hline Phule Dhanwantari & & 1 & 0.903 & 0.903 \\
\hline G.cernuum & & & 1 & 0.871 \\
\hline PA-812 & & & & 1 \\
\hline
\end{tabular}

Fig.1 Representative gel image showing parental polymorphism on four genotypes screened by 20 SSRs. M- 100 bp ladder, P1 - AKA-7, P2 - Phule Dhanwantari, D1 - G.arboreum race cernuum, D2 - PA812

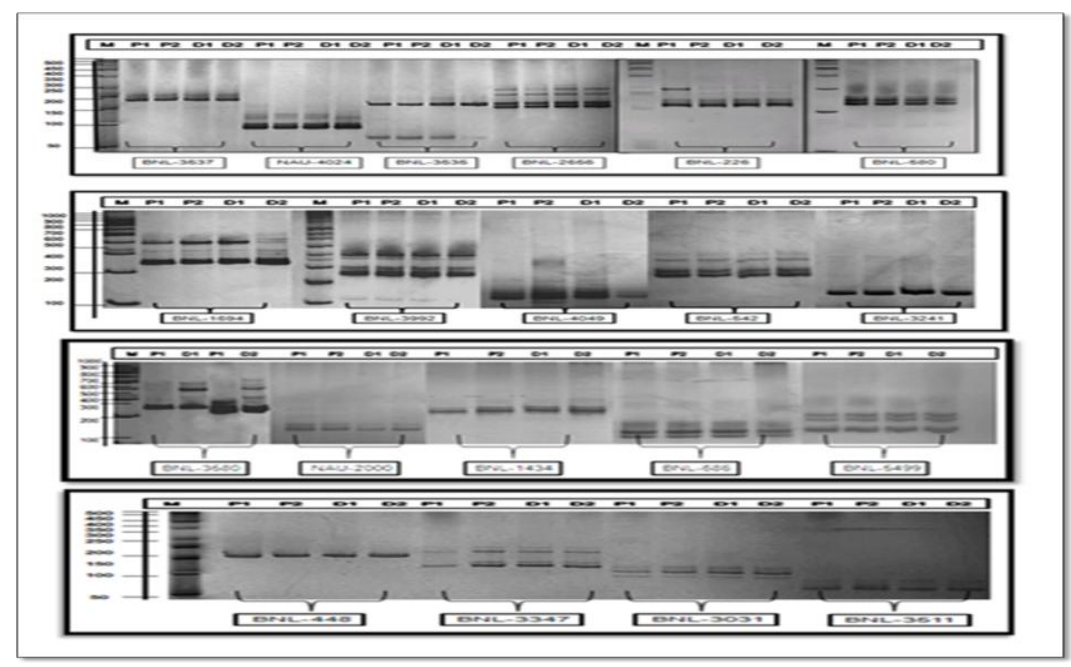


Fig.2 Graphical representation showing distribution of SSR markers used and polymorphism percent

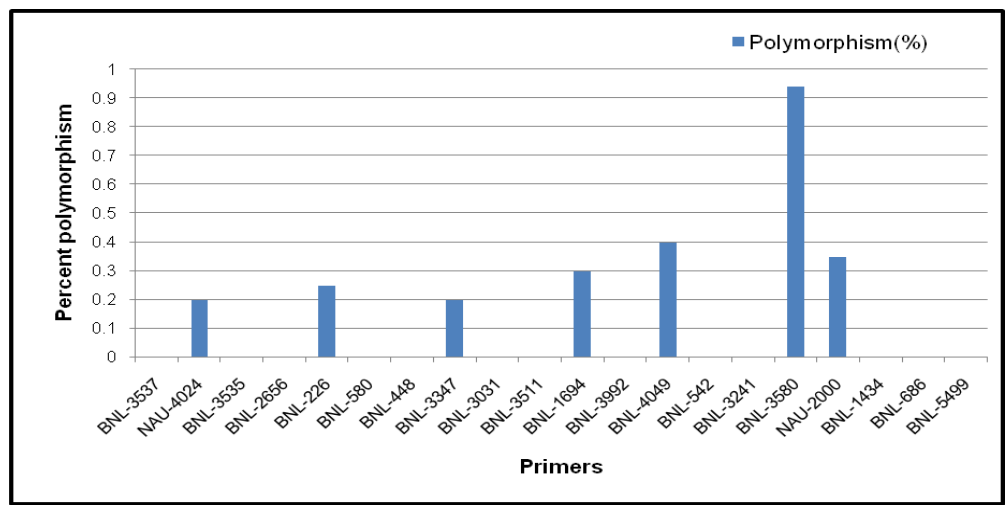

Fig.3 Dendrogram

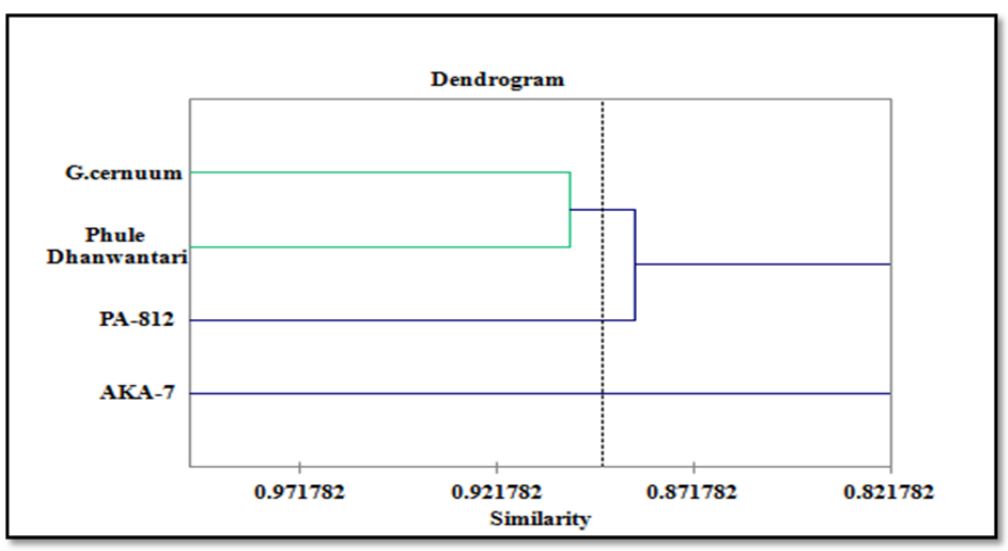

Fig.4 SSR amplification of the SC-I (AKA-7 x G. cernuum race) (a), SC-II (AKA-7 x PA-812) (b), SC-III (Phule Dhanwantari x G. cernuum race) (c) and SC-IV (Phule Dhanwantari x PA812) (d) with primer BNL-3580. The sequence of lanes is female parent, male parents and hybrids

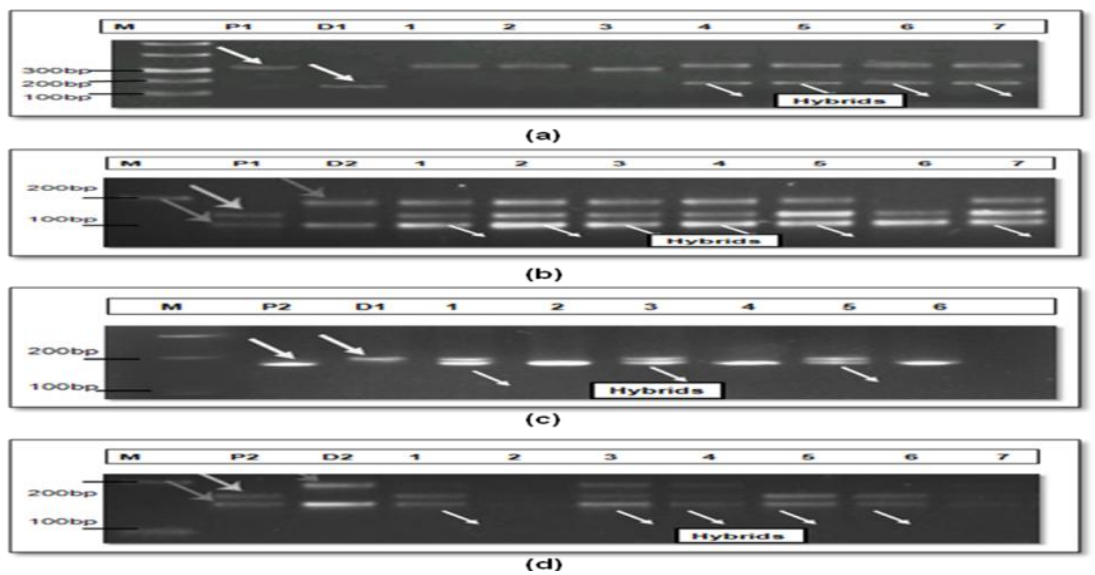


Similarly, BNL-3580 primer demonstrated specific allele in female parent $\mathrm{P}_{1}$ (AKA-7) and specific allele in male parent $\mathrm{D}_{2}$ (PA-812) i.e, in SC-II. However, single cross hybrid obtained from SC-II exhibited the alleles of both parents, confirming the heterozygosity of the hybrid. Fig. 4(b) depicts gel pictures demonstrating amplification in the parents and hybrids, Lane no.1, 2, 3, 4, 5 and 7 showing alleles of both of its parents are confirmed as true hybrids.

In the analysis of single cross-III BNL-3580 primer demonstrated specific allele in both female $\mathrm{P}_{2}$ (Phule Dhanwantari) and male parent $\mathrm{D}_{1}$ (G.cernuum). However, single cross hybrid obtained from SC-III exhibited the alleles of both parents, confirming the heterozygosity of the hybrid. Fig. 4(c) depicts gel pictures demonstrating amplification in the parents and hybrids, the $\mathrm{F}_{1} \mathrm{~s}$ from lane no.1, 3 and 5 shows both the amplicons from both of its parents indicating that these single cross $\mathrm{F}_{1} \mathrm{~s}$ are true hybrids obtained from crossing of the respective parents.

In the analysis of single cross-IV BNL-3580 primer demonstrated specific allele in both female $\mathrm{P}_{2}$ (Phule Dhanwantari) and male parent $\mathrm{D}_{2}$ (PA-812). However, single cross hybrid obtained from SC-IV exhibited the alleles of both parents, confirming the heterozygosity of the hybrid. Fig. 4(d) depicts gel pictures demonstrating amplification in the parents and hybrids, the $\mathrm{F}_{1} \mathrm{~s}$ from lane no.1, 3, 4, 5 and 6 shows both the amplicons from both of its parents indicating that these single cross $F_{1} s$ are true hybrids obtained from crossing of the respective parents. The SSR analysis for identification of true hybrids revealed that a total of 18 from 55 successful single crosses obtained were confirmed as true hybrids.

Effective identification of a true hybrid can be identified at maturity using a morphological basis. To develop a breeding system, it is important to pick true hybrids but it is difficult to decide before flowering. Use the SSR method, early-stage detection of true hybrids is simpler. BNL-3580 can be used for the unambiguous detection of these hybrids as a reference marker.

In conclusions the parental polymorphism survey by microsatellite assay showed the difference between parents used in hybridization programme. The genetic makeup of these four released popular genotypes differed for boll size, locule retention and other morphological traits. Among twenty SSR studied, seven markers shows polymorphism and BNL-3580 was found highly polymorphic $94 \%$. These identified markers will be helpful for tagging the lines with trait of interest. The 18 confirmed positive plants of four single cross hybrids will be useful in genome conversion by attempting two double cross hybrids and single multi cross hybrid. A stable, homozygous and improved line of AKA-7 and Phule Dhanwantari possessing big boll can be developed in context to benefit farmers by cultivating desi cotton.

\section{Acknowledgements}

Authors like to express their gratitude to Dr. PDKV, Akola for providing grants, Biotechnology Centre and Cotton Research Unit Dr. PDKV, Akola for providing seed material. The assistance provided by Dr. P. V. Jadhav, Dr. Krishnananda $\mathrm{P}$ Ingle, Mr. Balvant Munde, and Dr. Amrapali Akahre was greatly appreciated.

\section{References}

Abdalla, A.M., OUK. Reddy, K.M. El-Zik and A.E. Pepper, 2001. Genetic diversity and relationships of diploid and tetraploid cottons revealed using 
AFLP. Theor Appl Genet. 2001; 102: 222-229. doi: 10.1007/s001220051639.

Akhtar K.P., S. Haidar, MKR. Khan, M. Ahmad, N. Sarwar 2010. Evaluation of Gossypium species for resistance to cotton leaf curl Burewela virus. Ann. Appl. Biol. 157:135-147. http://dx.doi.org/10.1111/j.17447348.2010.00416.x

Alkuddsi, Y.A., S.S. Patil, S.M. Manjula, H.L. Nadal, B.C. Patil, 2013. Relationship between SSR-based molecular marker and cotton $\mathrm{F}_{1}$ Inter specific hybrids performance for seed cotton yield and fiber properties. Genomics Applied Biology, Vol.4, No.4 DOI: 10.5376/gab.2013.04.0004.

Brown, J.S, 1958. Principle component and analysis of cotton variability across the US cotton belt Am. J. Bot., 81:13091326.

Brown, W.L, 1983. Genetic diversity and genetic vulnerability - an appraisal. Econ. Bot. 37(1): 4-12

Dhawan, A.K., G.S. Simwat, A.S. Sidhu, 1991. Field reaction of some varieties of Asiatic cotton (Gossypium arboreum L.) to sucking and boll worm pests. J Res. Punjab Agric. Uni. 28:57-62.

Han, Z., C. Wang, X. Song, W. Guo, J. Gou, C. Li, X. Chen, T. Zhang 2006. Characteristics development and mapping of Gossypium hirsutum derived EST-SSRs in allotetraploid cotton. Theor. Appl. Genet. 112:430439. http://dx.doi.org/10.1007/s00122005-0142-9

Lalitha, N., B. Ramaswami, P.K. Viswanathan, 2014. India's experience with Bt Cotton: Case studies from Gujarat and Maharashtra Article December 2014.

Litt, M and J.A. Lutty, 1989. A hypervariable microsatellite revealed by invitro amplification of a dinucleotide repeat within the cardiac muscle actin gene. Am. J. Hum. Genet. 44:397-401.

Liu, Z, 2007. Simulating the transient evolution and abrupt change of Northern Africa atmosphere-oceanterrestrial ecosystem in the Holocene Quaternary Science Reviews, 26 (2007) 1818-1837.

Mehetre, S.S., G.C. Shinde, S.U. Pardeshi, 2004. Status and strategies of host plant resistance for biotic stress in cotton. In: B.M. Khadi, I.S. Kategeri, S.S. Patil, H.M. Vamadevaiah, B.R. Patil and S.M. Manjula (Eds), proceedings of international symposium on "Strategies for Sustainable Cotton Production-A Global Vision"1, Crop Improvement, 23-25 November 2004, University of Agricultural Sciences, Dharwad, Karnataka (India), pp.31-47.

Naik, G. January 2005 Economic and political weekly 40(15):1514-1517

DOI:10.2307/4416465 Bt Cotton Controversy: Some Paradoxes Explained

Nibouche, S., T. Brevault, C. Klassou, D. Dessauw, B. Hau, 2008. Assessment of the resistance of cotton germplasm (Gossypium spp.) to aphids (Homoptera, Aphididae) and leafhoppers (Homoptera: Cicadellidae, Typhlocybinae): methodology ana genetic variability. Plant breed. 127:376-382.

http://dx.doi.org/10.1111/j.14390523.2008.01499.x

Percival, A.S. and R.J. Kohel, 1990. Distribution, collection and evaluation of Gossypium. Advances in Agronomy, volume 44, 1990, pages 225-256 DOI:10.1016/S00652113(08)60823-8.

Powell, W., G. C. Machray, J. Provan, 1996. Polymorphism revealed by simple sequence repeats. Trends Plant Sci. 
1:215-222.

http://dx.doi.org/10.1016/1360-

1385(96)86898-1

Rahman, M., N. Aslam, M. Asif, T.A. Malik, K.A. Malik, Y. Zafar, 2002a. Identification of DNA markers for cotton leaf curl disease (CLCD) in cotton (Gossypium hirsutum L.). Cotton Sci. 14:17.

Rao, P.S., P. Aruna, G. Anuradha, K. Kunosoth, 2015. Fingerprinting of Cotton (Gossypium Spp.) Hybrids and their Parental Lines Using Microsatellite Markers and their Utilization in Genetic Purity Assessment

DOI: $10.18005 / \mathrm{JAEB} 0303005$

Singh, J.P.N., R. Verma, P. Chaudhari, 2006. Random amplified polymorphic DNA (RAPD) analysis of Mycobacterium tuberculosis strains in India. J Vet Sci. Jun; $7(2)$ : 181-187

DOI: $10.4142 /$ jvs.2006.7.2.181

Sethi, K., P. Siwach and S.K. Verma, 2014. Genetic improvement of Gossypium arboreum L. using molecular markers:
Status and development needs. African Journal of Agricultural Research Vol. 9(29), pp. 2238-2249, 17 July, 2014 DOI: 10.5897/AJAR2014.8682.

Sethi, K., P. Siwach and S.K. Verma, 2015. Assessing genetic diversity among six populations of Gossypium arboreum L. using SSR markers. Physiol mol biol plant 2015 Oct; 21(4): 531-539.

Sharma, A.D., P.K. Gill and P. Sing, 2002. DNA isolation from dry and fresh samples of polysaccharide rich plants. Plant Molecular Biology Reporter, 20: 415a-415f

Wheeler. T.A., J.R. Gannaway, K. Keating, 1999. Identification of resistance to Thielaviopsis basicola in diploid cotton. Plant Dis. 83:831-833. http://dx.doi.org/10.1094/PDIS.1999.8 3.9.831

Xiang, X.L. and D.Z. Shen, 1989. Chinese Asian Cotton (Gossypium arboreum). China Agricultural Press, Beijing, China (in Chinese).

\section{How to cite this article:}

Meghraj T. Chavhan, D. R. Rathod, B. S. Taynath, P. N. Bhojane, S. B. Deshmukh, S. J. Gahukar, A. S. Bhande and Mohanapure, P. A. 2021. Molecular Characterization of Desi Cotton Hybrids using SSR Markers for Boll Size Improvement. Int.J.Curr.Microbiol.App.Sci. 10(01): 113-123. doi: https://doi.org/10.20546/ijcmas.2021.1001.013 